\title{
Age-season lactation curves for production traits of cows calving in Wielkopolska region of Poland
}

\author{
T. Strabel ${ }^{1}$ \\ August Cieszkowski Agricultural University, \\ Department of Genetic and Animal Breeding \\ Wotyńska 33, 60-637 Poznań, Poland
}

(Received 17 December 2003; revised version 19 April 2004; accepted 16 June 2004)

\begin{abstract}
The objective of this study was to estimate lactation curves for cows of different age at calving in winter and summer seasons. Data consisted of 1289522 test-day records of cows calved in Wielkopolska region in 1992-1996. Milk, fat and protein yields in first three parities were studied. Test-day model with 50 classes of days-in-milk by parity was used. Lactation curves were derived from solutions for this effect. They were flatter for first versus later lactations. Peak yield for milk production occurred in the second part of the first month of production. Shape of lactation curves for different age and season classes did not vary substantially. Cows calving in winter season had higher production. Similarly, older cows had higher yields for all traits and lactations, however the evidence of age at calving by season of calving interaction was found.
\end{abstract}

KEY WORDS: dairy cows, lactation curve, milk traits, test-day records

\section{INTRODUCTION}

A lactation curve depicts cow's milk yield after colostrum to drying-off showing the peak production level, persistency, and the effects of specific events on milk production. Several models have been proposed to estimate lactation curves based on monthly recorded daily yields (for a review see Swalve, 1995). In a multitrait model, yields on each test-day are treated as separate traits (Trus and Buttazzoni, 1990). In test-day models (TDM) observations are treated as repeated measurements of the same trait. Partitioning lactation in days-in-milk (DIM)

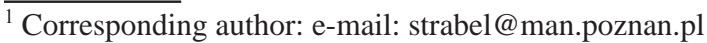


classes enables calculating estimates of the effects of DIM on daily production (Keown et al., 1986). Another approach is to use lactation curve functions in testday models to model average yields by DIM. This method reduces the number of parameters which need to be estimated however, the artifacts of the function used may influence the results.

TDM are preferred to lactation models for analysis of milk production traits in dairy cattle, because of their better ability to model non-genetic effects associated with individual test-days. The influence of environmental effects such as age and season of calving, stage of lactation, region, herd and number of days open on test-day yields was presented in numerous studies (Stanton et al., 1992; Norman et al., 1995; Bormann et al., 2002). The most common non-genetic effect in TDM is herd-test-day effect, which accounts for effects specific to a day of test. The use of TDM implies that the effect of age and season of calving specific to individual DIM can be accounted for.

The effect of age at calving on daily yields depends on the calving month, parity and level of production (Auran, 1973; Danell, 1982; Wilmink, 1987). Age at calving accounts for $2-41 \%$ of the total variation in test-day milk yields (Auran, 1973), depending on the stage of lactation.

Month and season of calving has also significant impact on milk traits as was shown in previous studies (Danell, 1982; Stanton et al., 1992; Norman et al., 1995; Swalve, 1995). Season is usually modeled jointly with herd and year effect and accounts for most of the non-genetic variation. Month of the test effect is more efficient in accounting for seasonal variation than month of the test (Strabel and Szwaczkowski, 1995).

Interactions between non-genetic effects also influence daily yields. Ptak et al. (1993) found significant interaction between age and month of calving with year of calving. In TDM lactation curves are usually nested in classes regarding levels of such effects as: age, season, time period and region (Schaeffer et al., 2000).

The aim of this study was to estimate lactation curves of cows calving in different ages and seasons using a TDM. Milk, fat and protein yields in first three lactations of cows from Wielkopolska region were analysed.

\section{MATERIAL AND METHODS}

Data consisted of 1289522 TD records of 89579 Polish Black-and-White cows calving in 1988 herds in Wielkopolska region from July 1992 through June 1996. Most of the cows were crossbreds with average percentage of Holstein-Fresian (HF) less than 50\%. Only TD records from 5-305 DIM were included. The average number of TD records per lactation was 9. Number of TD records per lactation as well as means and standard deviations for milk, fat and protein yields are presented in Table 1. 
TABLE 1

Number of test-day records, means and standard deviations for milk, fat and protein yield per lactation

\begin{tabular}{lcrc}
\hline $\begin{array}{l}\text { Traits and } \\
\text { lactations }\end{array}$ & $\begin{array}{c}\text { No. of } \\
\text { TD }^{1}\end{array}$ & Mean & SD \\
\hline I lactation & 577962 & 14.26 & 4.99 \\
milk, kg & & 0.58 & 0.22 \\
fat, kg & & 0.45 & 0.15 \\
protein, kg & & & \\
II lactation & 417586 & 15.39 & 6.05 \\
milk, kg & & 0.64 & 0.26 \\
fat, kg & & 0.50 & 0.19 \\
protein, kg & & \\
III lactation & 293974 & 15.99 & 6.33 \\
milk, kg & & 0.66 & 0.28 \\
fat, kg & & 0.52 & 0.19 \\
protein, $\mathrm{kg}$ & & & \\
\hline
\end{tabular}

${ }^{1} \mathrm{TD}$ - test-days

Records from the first three lactations were analysed simultaneously. The following model for analysis of each trait was used:

$$
\mathrm{y}_{\mathrm{ijklmno}}=\mathrm{HTD}_{\mathrm{i}}+\operatorname{DIM}_{\mathrm{k}} \times \mathrm{AGE}_{\mathrm{o}} \times \operatorname{SEASON}_{\mathrm{j}}+\mathrm{a}_{\mathrm{ml}}+\mathrm{p}_{\mathrm{ml}}+\mathrm{e}_{\mathrm{ijklmno}}
$$

where: $\mathrm{y}_{\mathrm{ijk} \mid \mathrm{knno}}$ is $\mathrm{n}$-th test-day record (milk, fat or protein yield) for lactation 1 of cow $\mathrm{m}$, within herd-test-day (HTD) effect $\mathrm{i}$, calving in the j-th SEASON, belonging to the o-th class of AGE, from the $\mathrm{k}$-th class of DIM; $\mathrm{a}_{\mathrm{ml}}$ is a genetic effect of animal $m$ in lactation $1, p_{m l}$ is a random permanent environmental effect, $e_{i \mathrm{ijkmno}}$ is a residual effect.

The effect of DIM was represented by 40 five-day classes through 205 daysin-milk and 10 ten-day classes from 206 through 305 days-in-milk. The AGE effect was defined as age at calving and it was represented by the following classes: months: from 18 to 25,26 to 27,28 to 29,30 to 31 and from 32 to 42 for first calving, and from 29 to 38,39 to 41,42 to 44 and from 45 to 60 for second calving and from 39 to 52,53 to 56 and from 57 to 75 for third calving. Two seasons of calving were distinguished: winter (October-March) and summer (April-September). Numbers of TD records from above age-season classes are presented in Table 2. 
TABLE 2

Number of test-day records by parity, age at calving and season of calving

\begin{tabular}{|c|c|c|c|c|c|}
\hline \multicolumn{2}{|c|}{ I parity } & \multicolumn{2}{|c|}{ II parity } & \multicolumn{2}{|c|}{ III parity } \\
\hline $\begin{array}{c}\text { age } \\
\text { months }\end{array}$ & $\begin{array}{l}\text { test- } \\
\text { day }\end{array}$ & $\begin{array}{c}\text { age } \\
\text { months }\end{array}$ & $\begin{array}{l}\text { test- } \\
\text { day }\end{array}$ & $\begin{array}{c}\text { age } \\
\text { months }\end{array}$ & $\begin{array}{l}\text { test- } \\
\text { day }\end{array}$ \\
\hline \multicolumn{6}{|c|}{ Summer season } \\
\hline $18-25$ & 50303 & $29-38$ & 43891 & $39-52$ & 49467 \\
\hline $26-27$ & 67152 & $39-41$ & 60690 & $53-56$ & 48904 \\
\hline $28-29$ & 65933 & $42-44$ & 49166 & $57-75$ & 42752 \\
\hline $30-31$ & 45583 & $45-60$ & 47583 & & \\
\hline $32-42$ & 46249 & & & & \\
\hline \multicolumn{6}{|c|}{ Winter season } \\
\hline $18-25$ & 59762 & $29-38$ & 53593 & $39-52$ & 59897 \\
\hline $26-27$ & 69236 & $39-41$ & 58427 & $53-56$ & 45589 \\
\hline $28-29$ & 61981 & $42-44$ & 48127 & $57-75$ & 47365 \\
\hline $30-31$ & 48131 & $45-60$ & 56109 & & \\
\hline $32-42$ & 63632 & & & & \\
\hline
\end{tabular}

Variance-covariance components were estimated using REMLF90 (Misztal et al., 2002) based on records from randomly selected herds that contained 6347 cows. Cows in this subset having second and third lactation were required to have their previous lactations records. The variance-covariance matrix for additive-genetic effect included numerator relationship matrix. Both variance-covariance matrices for additive-genetic and permanent environmental effects included covariances between different parities. Different residual variances for different lactations were used but the same within lactation. Residuals were assumed to be uncorrelated between lactations.

Solutions for DIM $\times$ AGE $\times$ SEASON classes were obtained using BLUPF90 program (Misztal et al., 2002). Lactation curves were plotted using solutions for $\mathrm{DIM} \times \mathrm{AGE} \times$ SEASON classes. Mean solution for HTD effect was added to DIM $\times$ AGE $\times$ SEASON estimate for each trait and parity. The cumulated effect of ageseason classes was calculated by summing solutions for DIM across lactation and setting to zero solutions for first age and summer season classes for each parity.

\section{RESULTS}

Lactation curves for cows calving in winter season at the age from the most frequent age classes for milk, fat and protein yields are shown in Figure 1. For all traits lactation curves of different parities differed in shape and level. In general, higher parity curves described higher production. 

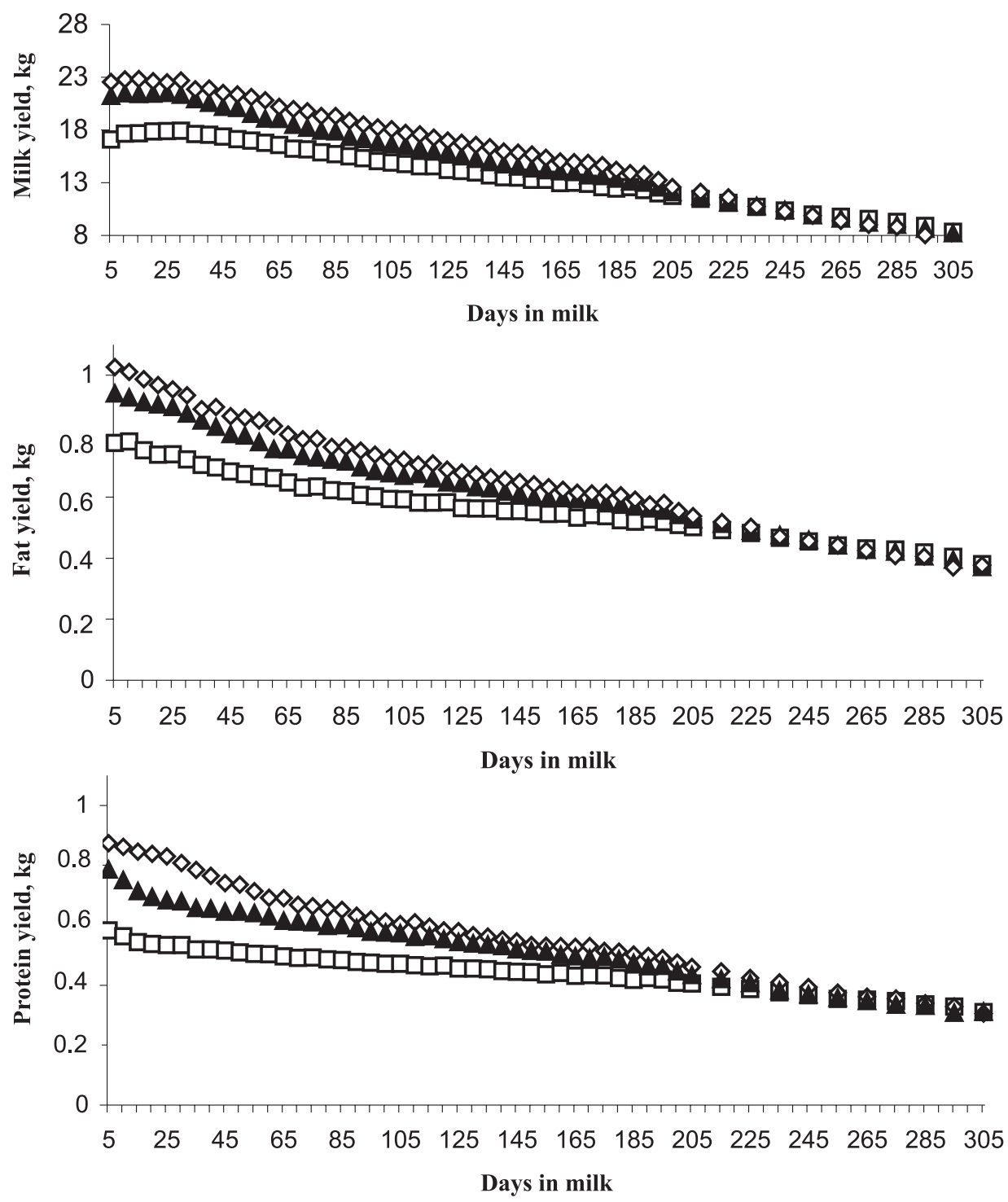

Figure 1. Lactation curves for milk, fat and protein for cows calving in winter season at age of 26-27 months ( $\square$ ), 39-41 months $(\boldsymbol{\Delta})$ and 53-56 months $(\diamond)$ for first, second and third parity, respectively

Lactation curves of primiparous cows were more persistent than those for multiparous cows. The peak production of cows in first lactation was lower and yields of these cows after 210 days exceeded production of cows in second and third parities. Lactation curves of multiparous cows were slightly depressed at approximately 200-210 DIM. 
Milk yields peaked at different DIM depending on parity and age-season classes (Table 3). The maximum yield for the first parity was observed between 21 and 35 DIM. In general, the number of day-in-milk at which a peak was observed slightly decreased with increasing parity number. No peak for fat and protein yields occurred.

TABLE 3

Days-in-milk for maximum milk yield by parity, age at calving and season of calving

\begin{tabular}{|c|c|c|c|c|c|}
\hline \multicolumn{2}{|c|}{ I parity } & \multicolumn{2}{|c|}{ II parity } & \multicolumn{2}{|c|}{ III parity } \\
\hline $\begin{array}{c}\text { age } \\
\text { months }\end{array}$ & $\mathrm{DIM}^{1}$ & $\begin{array}{c}\text { age } \\
\text { months }\end{array}$ & $\mathrm{DIM}^{1}$ & $\begin{array}{c}\text { age } \\
\text { months }\end{array}$ & DIM $^{1}$ \\
\hline \multicolumn{6}{|c|}{ Summer season } \\
\hline $18-25$ & $26-30$ & $29-38$ & $25-30$ & $39-52$ & $11-15$ \\
\hline $26-27$ & $26-30$ & $39-41$ & $16-20$ & $53-56$ & $21-25$ \\
\hline $28-29$ & $31-35$ & $42-44$ & $21-25$ & $57-75$ & $21-25$ \\
\hline $30-31$ & $21-25$ & $45-60$ & $26-30$ & & \\
\hline $32-42$ & $21-25$ & & & & \\
\hline \multicolumn{6}{|c|}{ Winter season } \\
\hline $18-25$ & $26-30$ & $29-38$ & $16-20$ & $39-52$ & $16-20$ \\
\hline $26-27$ & $31-35$ & $39-41$ & $25-30$ & $53-56$ & $16-20$ \\
\hline $28-29$ & $21-25$ & $42-44$ & $16-20$ & $57-75$ & $21-25$ \\
\hline $30-31$ & $26-30$ & $45-60$ & $11-15$ & & \\
\hline $32-42$ & $26-30$ & & & & \\
\hline
\end{tabular}

${ }^{1}$ DIM - days-in-milk

Figure 2 shows first lactation milk yield curves for cows of different ages calved in summer season. Older cows had higher yields but the shapes of lactation curves for cows of different ages did not differ. Similar results were obtained for other traits and parities (results not shown).

Plotting curves for cows of selected ages and both seasons (Figure 3) showed that production of cows calving in winter was higher, in particular, in the first 200 DIM.

Higher production of cows calved in winter season was confirmed on Figure 4 where cumulated effects of cows of different age calving in both seasons are presented. Cows calving in winter produced on average $150 \mathrm{~kg}$ more milk, over $5 \mathrm{~kg}$ more fat and over $4 \mathrm{~kg}$ more protein in all parities (Figure 4).

The advantage of winter calvings for milk and fat yield was higher in third parity and lower in second parity of all traits.

Effect of age and season of calving cumulated over 305 DIM is shown on Figure 4. In general, production increases with age in both seasons of first and second lactation. Higher production of cows calving in winter than in 


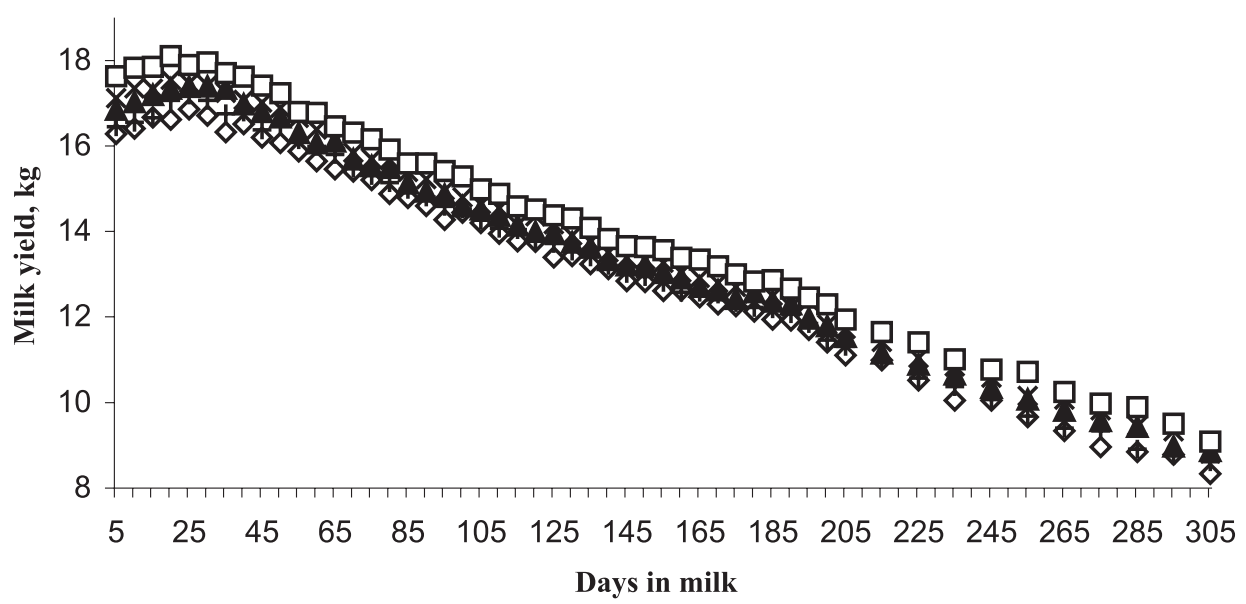

Figure 2. Lactation curves for milk yield of first parity cows calved in summer season, by age classes

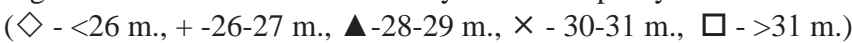

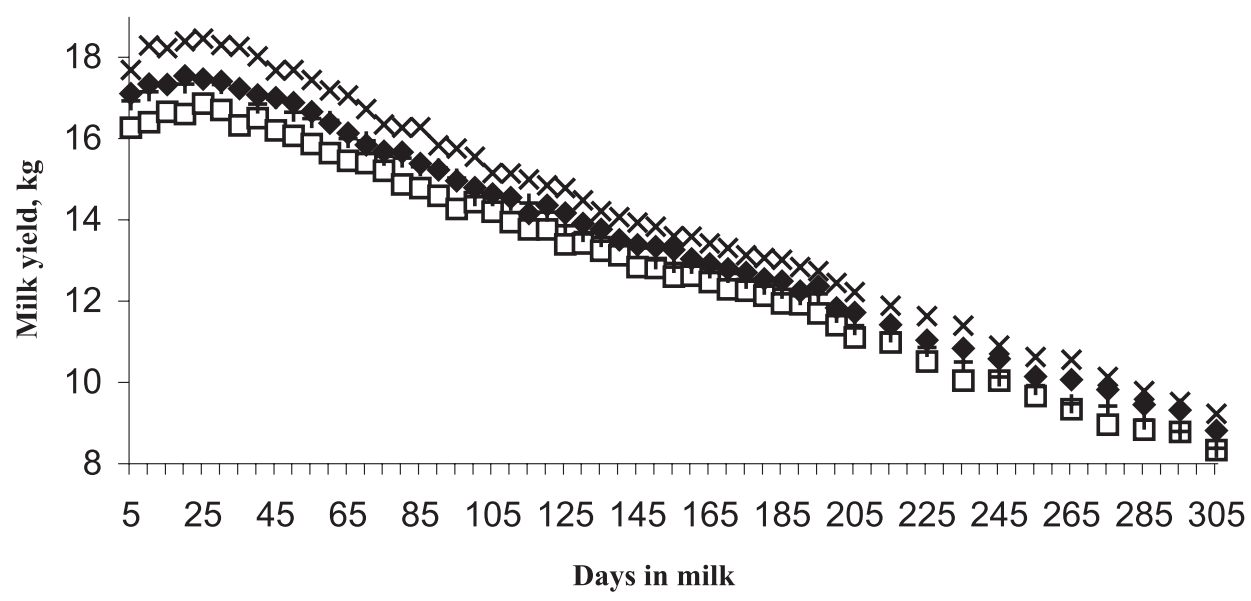

Figure 3. Lactation curves for milk yield of first parity cows calved in selected age classes and both seasons: less than 26 months of age in summer ( $\square$ ) and winter (+) seasons and at 30-31 months of age in summer $(\diamond)$ and winter season $(\times)$

summer is confirmed. However, milk, fat and protein yield of the oldest group of cows in third lactation calving in winter was not higher than production of younger class of cows, what suggests existence of age and season interaction. 

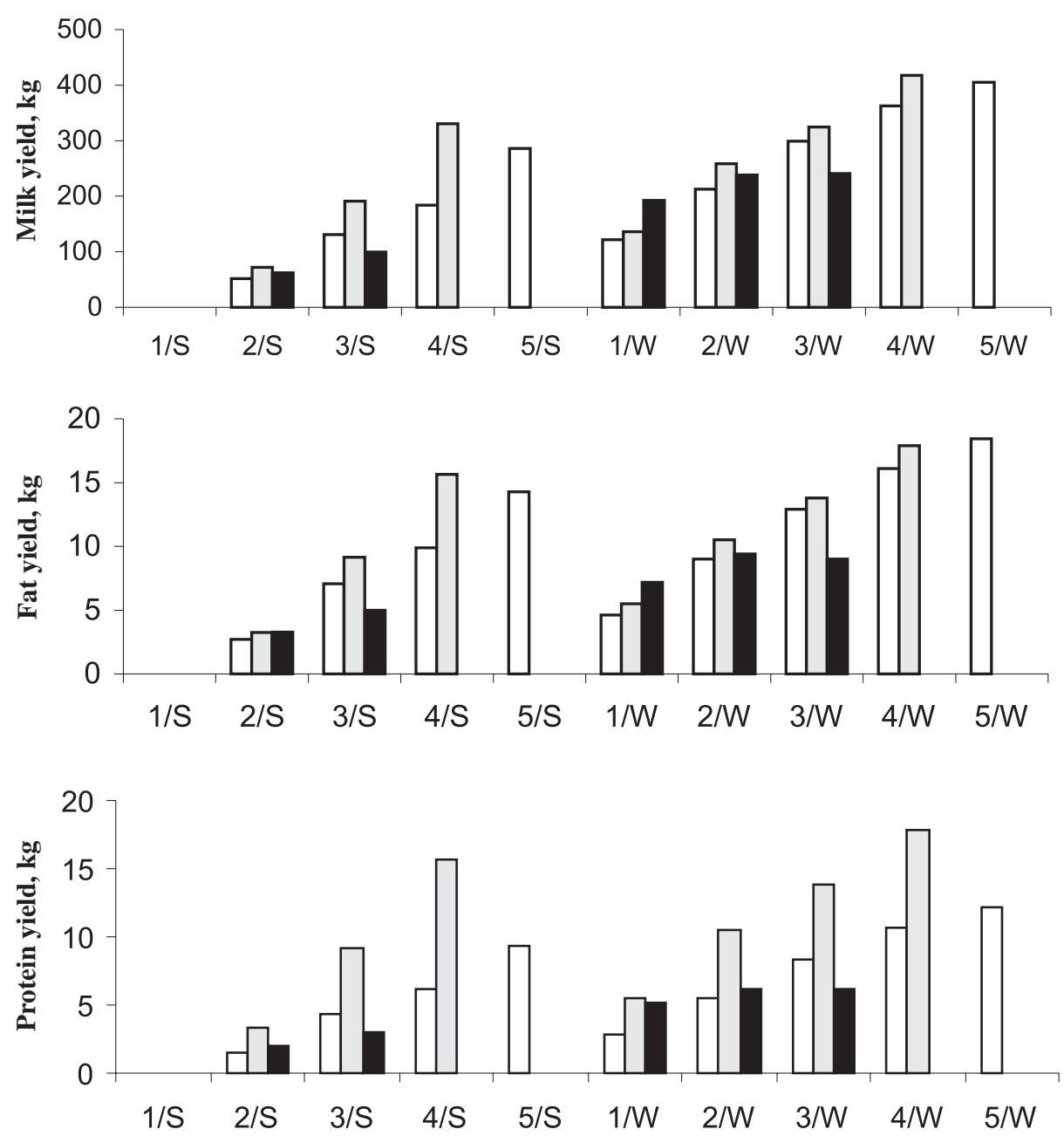

Figure 4. Effect of different age classes (1-5) cumulated over 305 DIM for milk, fat and protein yield for the first (white bars), second (gray bars) and third parity (black bars) and summer (S) and winter (W) seasons. Effect of first lactation summer calvings for the youngest group of cows was set to zero

\section{DISCUSSION}

Different shapes of lactation curves for different traits and parities were consistent with results reported by other authors (Shanks et al., 1981; Danell, 1982; Keown et al., 1986). Lower peak for milk yield of primiparous cows and lower persistency for multiparous cows have been also reported and discussed in numerous previous studies (Danell, 1982; Keown et al., 1986; Stanton et al., 1992; Bormann et al., 2002). 
The observed peak in milk yield appeared earlier when compared to other studies (Schutz et al., 1990; Stanton et al., 1992; Bormann et al., 2002). Typically, peak for milk yield of Holsteins is observed at approximately 45 DIM what could be the consequence of higher level of production when compared to average yield of cows analysed in this study. Lower productivity of Lowland cattle is caused by worse environmental condition and differences in genotypes. Early peak for milk yield was reported also by Ptak and Żarnecki (1998). In that study peak for milk yield occurred later for a group of higher producing cows with higher amount of HF genes.

In general, lactation curves for first lactation yield traits have been found to be more persistent than later lactation curves in many studies (Danell, 1982; Keown et al., 1986; Stanton et al., 1992; Tekerli et al., 2000; Bormann et al., 2002). Cows in first lactation still grow which counterbalances the typical decline in milk yield as the lactation progresses. Higher persistency of the first lactation milk yield is also the natural consequence of the lower peak for this parity - lactations with higher peak have usually a steeper declining slope after peak.

No particular reason can be presented to explain the slight decline of multiparous lactation curves at the beginning of the third trimester.

Grossman et al. (1986) studied influence of environmental effects on the shape of the lactation curve. Parameters describing curves did not differ between age classes. This is in agreement with results found in this study, which showed the lack of age effect on the shape of lactation curve. Several other papers however, showed the decreasing effect of age at calving towards the end of the lactation (Auran, 1973; Danell, 1982; Wilmink, 1987; Pander et al., 1992; Jamrozik et al., 1997).

Increasing milk production with age was reported in many studies (Auran, 1973; Danell, 1982; Juszczak et al., 2001; Bormann et al., 2002). Positive association between age and yield within each lactation, smaller for further parities, was also found in the study of Khan and Shook (1996). Increase in the age solutions within lactations have been partly attributed to differences in number of days open by Wiggans and VanRaden (1994). In this study this effect was not included in the model due to lack of this information.

Differences in first lactation milk yield among cows calving at different ages estimated by Khan and Shook (1996) were much higher than observed in this study. The lower impact of age on milk yield could be caused by the fact that mean production of cows from Wielkopolska region is lower than reported in the cited study.

The effect of season of calving on the shape of the lactation curve was reported also in other studies. Grossman et al. (1986) showed that month of freshening has impact on most of the parameters describing the lactation curve. Danell (1982) found lactations of cows calving in summer and autumn to be more persistent than those calving at the end of winter and in spring. Higher persistency for cows that calved in summer and fall was also found in the study of Tekerli et al. (2000). 
However, that observation cannot be compared with results from this study where lactation, which began in summer and autumn, belonged to two separate classes.

Ptak and Żarnecki (1998) estimated milk yield lactation curves for different ages, seasons and genetic groups. For cows with more than $75 \%$ of Holstein-Friesian genes they observed increased production in first two trimesters during winter seasons, what, similarly to results in this study, make lactations less persistent than lactations of cows calving in summer.

The greatest differences between seasons observed for the third parity curves are in agreement with observation of Stanton et al. (1992). However, the impact of season effect on yield traits in this study was much smaller: cows calving in winter in Wielkopolska region produced no more than $1 \mathrm{~kg}$ milk in the first part of lactation while milk yield for cows analysed by Stanton et al. (1992) produced at peak $3 \mathrm{~kg}$ more milk. The observed small influence of season could be caused by generally lower productivity of cows used in this study.

Lactation yields for cows that calved in fall and winter are usually higher (Danell, 1982; Norman et al., 1995; Khan and Shook, 1996; Tekerli et al., 2000) which was also confirmed in this study. More TD records from cows calving during winter season suggest that it is a common practice for farmers to take advantage of this fact. However, the advantage of winter calvings of less than $170 \mathrm{~kg}$ of milk for each parity is much lower than the seasonal fluctuation estimated by Khan and Shook (1996).

Unequal effects of age on production traits in lactations from different seasons confirmed the existence of age-season interaction. This supports results of Ptak et al. (1993) who found significant interaction of age and month of calving with year of calving. Data in this study represented relatively short period of time so this kind of interaction was not analysed. Based on the results from this study, nesting lactation curves within age-season subclasses for the purpose of genetic evaluation seems to be appropriate.

\section{ACKNOWLEDGEMENT}

The authors thank Poznań Supercomputing and Networking Center, Poland, for access to the computer. 


\section{REFERENCES}

Auran T., 1973. Studies on monthly and cumulative monthly milk yield records. 1 . The effect of age, month of calving, herd and length of the first period. Acta Agr. Scand. 24, 189-199

Bormann J., Wiggans G.R., Philpot J.C., Druet T., Gengler N., 2002. Estimating effects of permanent environment, lactation stage, age, and pregnancy on test-day yield. J. Dairy Sci. 85, Online. Available: http://www.adsa.org/jds/papers/2002/d0210264.pdf.

Danell B., 1982. Studies on lactation yield and individual test-day yields of Swedish dairy cows. 1. Environmental influence and development of adjustment factors. Acta Agr. Scand. 32, 65-81

Grossman M., Kuck A.L., Norton H.W., 1986. Lactation curves of purebred and crossbred dairy cattle. J. Dairy Sci. 69, 195-203

Juszczak J., Machal L., Hibner A., 2001. Calving age of heifers as a factor of the efficiency of cattle dairy performance (in Polish). Prz. Hod. 69 (5), 18-20

Jamrozik J., Schaeffer L.R., Dekkers J.C.M., 1997. Genetic evaluation of dairy cattle using test day yields and random regression model. J. Dairy Sci. 80, 1217-1226

Keown J.F., Everett R.W., Empet N.B., Wadell L.H., 1986. Lactation curves. J. Dairy Sci. 69, 769781

Khan M.S., Shook G.E., 1996. Effects of age on milk yield: Time trends and method of adjustment. J. Dairy Sci. 79, 1057-1064

Misztal I., Tsuruta S., Strabel T., Auvray B., Druet T., Lee D.H., 2002. BLUPF90 and related programs (BGF90). Proceedings of the 7th World Congress on Genetics Applied to Livestock Production. Montpellier (France), 33, 743-744

Norman H.D., Meinert T.R., Schutz M.M., Wright J.R., 1995. Age and seasonal effects on Holstein yield for four regions of the United States over time. J. Dairy Sci. 78, 1855-1861

Pander B.L., Hill W.G., Thompson R., 1992. Genetic parameters of test day records of British Holstein-Friesian heifers. Anim. Prod. 55, 11-21

Ptak E., Horst H.S., Schaeffer L.R., 1993. Interaction of age and month of calving with year of calving for production traits of Ontario Holsteins. J. Dairy Sci. 76, 3792-3798

Ptak E., Żarnecki A., 1998. Estimation of breeding values of Polish Black and White cattle using test day yields. Proceedings of the 6th World Congress on Genetics Applied to Livestock Production. Armidale (Australia), XXIII, 335-338

Schaeffer L.R., Jamrozik J., Kistemaker G.J., Van Doormaal B.J., 2000. Experience with a test-day model. J. Dairy Sci. 83, 1135-1144

Schutz M.M., Hansen L.B., Steurernagel G.R., Kuck A.L., 1990. Variation of milk, fat, protein and somatic cells for dairy cattle. J. Dairy Sci. 73, 484-493

Shanks R.D., Berger P.J., Freeman A.E., Dickinson F.N., 1981. Genetic aspects of lactation curves. J. Dairy Sci. 64, 1852-1860

Stanton T.L., Jones L.R., Everett R.W., Kachman S.D., 1992. Estimating milk, fat, and protein lactation curves with a test day model. J. Dairy Sci. 75, 1691-1700

Strabel T., Szwaczkowski T., 1995. Certain nongenetic effects on test-day milk yields in dairy cows. Anim. Sci. Pap. Rep. 13 (2/3), 55-64

Swalve H.H., 1995. Test day models in the analysis of dairy production data - a review. Arch. Tierzucht. 38, 591-612

Tekerli M., Akinci Z., Dogan I., Akcan A., 2000. Factors affecting the shape of lactation curves of Holstein cows from the Balikesir province of Turkey. J. Dairy Sci. 83, 1381-1386

Trus D., Buttazzoni L.G., 1990. A multiple trait approach to modeling the lactation curve. Proceedings of the 4th World Congress on Genetics Applied to Livestock Production. Edinburgh (Scotland), XIII, 492-495 
Wiggans G.R., VanRaden P.M., 1994. Effect of including parity-age classes on estimated genetic trend for milk and component yields. J. Dairy Sci. 77, Suppl. 1, 267 (Abstr.)

Wilmink J.B.M., 1987. Adjustment of lactation yield for age at calving in relation to level of production. Livest. Prod. Sci. 16, 321-334

\section{STRESZCZENIE}

\section{Krzywe laktacji dla cech produkcyjnych krów z rejonu Wielkopolski wycielonych w różnym} wieku i sezonie

Celem pracy było oszacowanie krzywych laktacji krów wycielonych w różnym wieku i sezonie. Materiał stanowiło 1289522 próbnych udojów krów wycielonych w regionie Wielkopolski w latach 1992-1996. Oznaczono wydajność mleka, tłuszczu i białka w pierwszych trzech laktacjach. Zastosowano model dla próbnych udojów z 50. przedziałami dla dni laktacji, odrębnymi dla poszczególnych laktacji. Krzywe laktacji uzyskano z rozwiązań dla tego efektu. Pierwsze laktacje były bardziej płaskie w porównaniu z kolejnymi. Szczyt laktacji stwierdzono w drugiej połowie pierwszego miesiąca laktacji. Krzywe laktacji dla poszczególnych klas wieku i sezonu nie różniły się znacznie. Produkcyjność krów wycielonych w sezonie zimowym była wyższa niż w letnim. Podobnie starsze krowy cechowała wyższa produkcyjność dla wszystkich cech i laktacji w porównaniu z krowami młodszymi. Stwierdzono także występowanie interakcji między wiekiem krów a sezonem wycielenia. 